\title{
Integration of Balanced Scorecard and Analytical Hierarchy Process as a Tool for Determining the Priority of the Program Strategy: Case Study in Dr.Tc.Hillers Maumere Hospital
}

\author{
Yosefina Andia Dekrita1, Rita Yunus ${ }^{2}$, Andi Batary Citta ${ }^{3}$ and Muhammad Yamin ${ }^{4}$ \\ ${ }^{1}$ Nusa Nipa University, Indonesia, e-mail: andiadekrita@yahoo.com \\ ${ }^{2}$ Tadulako University, Indonesia, e-mail: rytha plw.@yahoo.com \\ ${ }^{3}$ STIM Lasharan Jaya, Indonesia, e-mail: citta2585@gmail.com \\ ${ }^{4}$ IAIN Bone, Indonesia, e-mail: maipal@yahoo.com
}

\begin{abstract}
The purposes of this study are to measure hospital performance based on a combination of Balanced Scorecard method and Analytic Hierarchy Process method with four perspectives namely customer perspective, finance, internal business processes and learning and growth, and to determine the priority strategies that need to be implemented at Dr.TC. Hillers Hospital MAUMERE. The research methodology used in this study was a combination of Balanced Scorecard and Analytic Hierarchy Process with stages of research: preliminary observation, problem formulation, study objectives, literature review, performance measurement with Balanced Scorecard analysis and Analytic Hierarchy Process. Strategic programs prioritized are strategies for improving the quality of the care process in the first priority (16.14\%), then increasing income growth (13.76\%), improving service quality (12.62\%), improving the quality of HR $(15.23 \%)$, increasing revenue growth $(13.76 \%)$, integrated Hospital Information System (12.76), improving the quality of HR (12.23), Cost Efficiency (10.84\%), increasing patient satisfaction $(9.33 \%)$ and improving the quality of patient output $(8.86 \%)$ and network expansion $(3.03 \%)$. This research is limited to taking only two indicators from each perspective due to time so that constraints, so that further researchers can take with several other full indicators. The Analytic Hierarchy Process (AHP) method has the advantage of allowing assessors to capture both subjective and objective measures of organizational quality evaluation. By providing a useful mechanism for assessing the consistency of evaluation and alternative steps, Analytic Hierarchy Process reduces the bias in decision making. With a combination of Balanced Scorecard and Analytic Hierarchy Process, managers or decision makers can determine priority strategies that can be implemented in the company. This work shows the peculiarities of the structure and elements of the Balanced Scorecard, and the Analytic Hierarchy Process and the penetration in the homes of non-profit organizations.

Keywords: Balance Scorecard, Analytic Hierarchy Process, Priority Strategy
\end{abstract}

\section{Introduction}

The public hospital is one of the government agencies engaged in the public sector in the field of health service that is a non-profit organization. Regional public hospital business activities are social and economic in nature that prioritizing the best health services for the community. Public hospital as one of the government agencies must be able to provide accountability both financially and nonfinancially to the government and the community as service users. Therefore, a performance appraisal is needed that can be used by management to evaluate the performance and preparation of strategic planning in the future.

Performance appraisal is not only needed and carried out in the profit-oriented business, but also in hospital as non-profit organization. The development of hospital management, both from the management and operational aspect is strongly influenced by various demands from the environment, namely among others that the hospital is required to provide quality health services, and the cost of health services is controlled so that it will lead to patient satisfaction. 
Health care organizations today face increased pressures from the government, taxpayers, and patients for greater accountability. Managers and clients require better measures of organizational performance that can be used to orient their efforts to improve performance (Baker et al., 1995).

In the last three years, many families of patients complained about the service process that took place at Dr.TC. Hillers Hospital which was obtained both through the suggestion box and direct submission to the hospital management. Complaints conveyed regarding the slow handling of patients, lack of full attention from nurses in handling patients both in outpatient and inpatient care. Other complaints were also obtained from employees both medical and non-medical personnel that they were not given the opportunity to improve competencies, among others by attending training and the unfair treatment in developing competencies. Based on these complaints, the hospital always strives to plan strategies to make improvements in improving hospital performance.

The Balanced Scorecard (BSC) concept is a performance measurement system model that provides a comprehensive framework and a good solution in the performance measurement framework (Lee, et al., 2008). Balanced Scorecard performance management tools, although less useful in empirical testing (Bourne, Neely, Platts, \& Mills, 2002); (Hanne Nørreklit, 2000), arguably the dominant framework in performance management (Marr \& Schiuma, 2003); (Scott M. Shafera, H.Jeff Smitha, 2015), This has been offered by the inventors as a foundation for a new strategic management system (Kaplan and David Norton,1996).

A Balanced Scorecard is a contemporary management tool that is used to boost the organization's ability to double financing performance. The Balanced Scorecard has four perspectives: finance, customers, internal business processes, and learning and growth. Measurements on these indicators are needed in achieving the balance of performance measurement (Hussein Aljardali, Mazen Kaderi b, 2012).

Balanced Scorecard is a business strategy that is implemented so that it can be implemented and can measure organizational success. Thus, the Balanced Scorecard can be used as a tool to implement strategies. Moreover, the Balanced Scorecard can align various functions (divisions, departments, sections) so that all decisions and activities within each of these functions can be mobilized to achieve company goals and to meet demand and accountability and improve services. Balanced Scorecard is considered suitable for the non-profit organization for the Balanced Scorecard not only emphasizes the quantitative-financial aspect, but also a qualitative aspect, and nonfinancial. This is in accordance with the type of non-profit organization that puts profit as the main performance measure, but services that are qualitative and non-financial.

Most of the nonprofit organizations that have been examined in this paper are in the early stages of implementing a balanced scorecard. The balanced scorecard is often used as a measurement tool and not as a management system. In most cases, participating organizations have unexpected perspectives in their attitude to the balanced scorecard, because they do not adequately adjust it to the different requirements of nonprofit operations (Greiling, 2010).

For the nonprofit sector, in general, empirical studies conduct quantitative or qualitative research (Teemu Malmi, 2001); (Speckbacher, et al., 2003); (Schäffer \& Matlachowsky, 2008). This study often focuses on very large organizations, such as those listed on the German stock exchange. Kaplan (2002) interviewed nine nonprofit hospital managers. All hospitals are in the early stages of implementing a balanced scorecard. The introduction of a balanced scorecard takes an average of two years. Kaplan (2002, MS 194) report that pay-off from this business is an increase in measurable performance in competitive marketing positions, financial results and customer satisfaction. The reason for the causes of the balanced scorecard often helps to identify gaps in existing strategies (Kaplan, 2002). Greiling (2010) conducted quantitative empirical research which included 343 nonprofit social service providers. It is intended that management performance with the balanced scorecard approach is the least used in the nonprofit sector only 8.8 percent of nonprofit organizations have implemented a balanced scorecard, compared with 67.4 percent with an organization-specific financial performance measurement system. 
To support the Balanced Scorecard as a performance appraisal method can be combined with the Analytic Hierarchy Process (AHP) method. The Analytic Hierarchy Process method introduced is an effective tool for handling complex decision making and can help decision makers to set priorities and make the best decisions. By reducing complex decisions into a series of paired comparisons, and then synthesizing the results, AHP helps capture the subjective and objective aspects of a decision. In addition, AHP combines techniques that are useful for checking the consistency of decisionmaking evaluations, thereby reducing bias in the decision- making the process (Thomas L. Saaty, 1980).

Decision making, for which we gather most of our information, has become a mathematical science today (Thomas L. Saaty, 2008. It formalizes the thinking we use so that, what we must do to better decisions is transparent in all its aspects. We need to have some fundamental understanding of this most valuable process that nature endowed us with, to make it possible for us to make choices that help us survive. Decision making involves many criteria and sub criteria used to rank the alternatives of a decision. Not only does one need to create priorities for the alternatives with respect to the criteria or sub criteria in terms of which they need to be evaluated, but also for the criteria in terms of a higher goal, or if they depend on the alternatives, then in terms of the alternatives themselves.

The research objectives on management strategies are mostly dominated by planning content and long-term strategies rather than actual strategy implementation, where little is written or researched. The reasons put forward for the scarcity of this research effort include that the field of strategy implementation is considered less "glamorous" as a subject area, and that researchers often underestimate the difficulties involved in investigating such topics - especially because they are thought to be fundamentally lacking in conceptual models (Helen Atkinson, 2006). More problems "practical" associated with the implementation of the strategy, in the meantime, including the difficulty of communication and a "low" level of middle management skills (Campbell,1991); (David OtleyU, 1999); (Michael Beer and Russell A.Eisenstat, 1996).

Therefore, the combination of Balanced Scorecard and Analytical Hierarchy Process in this study is expected to know the priority level in the program strategy of each Key Performance Indicator (KPI) so that it can be implemented in Dr.TC. Hillers Hospital.

Balanced Scorecard Concept. According to Kaplan and Norton (1996), Balanced Scorecard consists of two words, namely: Scorecard: a card used to record scores person's performance results that will be used to compare with actual performance results. Balanced: Shows that the performance of personnel or employees is measured in a balanced manner and viewed from two aspects, namely financial and non-financial, short-term and long-term and in terms of internal and external. The Balanced scorecard emphasizes that financial and nonfinancial measures are all part of a system that gives information to every part of the organization (Peter C.Brewer, 2000).

The Balanced Scorecard is a management system for implementing strategies, measuring performance that is not only financially but also involves the non-financial side, and to communicate the expected vision, strategy, and performance. In other words, performance measurement is not carried out solely for the short term, but also for the long term( Kaplan and Norton, 1996).

Performance measurement with the Balanced Scorecard is an alternative performance measurement based on four main things, namely finance, customers, internal business processes, learning, and growth. The advantage of using the Balanced Scorecard is that the Balanced Scorecard approach strives to translate the company's mission and strategy into goals and measurements that are viewed from four perspectives: finance, customers, internal business processes, learning, and growth.

The Balanced Scorecard approach extends into linking employee rewards to performance in all four areas, with suitable weightings applied to reflect the relative importance of each area. In some instances, companies see the non-financial measures of such importance that a "threshold" level of performance is set for each of the non-financials. Only if an individual exceeds these threshold levels, can they qualify for performance-related rewards linked to the financial performance results? This approach clearly indicates to employees the level of importance the organization places on future 
capability building and strategic issues, while at the same time recognizing shorter-term financial performance (Chavan, 2009).

The balanced scorecard method provides a comprehensive framework to describe the vision into the strategic objectives. Comprehensive strategy objectives can be formulated because of the balanced scorecard method (Robert S.Kaplan and David Norton, 1996)uses four perspectives: financial, customer, internal business processes, learning and growth. The summary of the elaboration of the four perspectives is as follows:

1) Financial perspective, providing financial goals that need to be achieved by the organization in realizing its vision, which consists of Gross operating income, Return On Investment (ROI), Return On Equity (ROE), Sales Growth (SG) or Economic Value Added (EVA), Revenue Growth (RG), Cost Growth (CG).

2) Customer perspective provides an overview of the target market segments and customers along with the demands of the needs served by the organization to achieve certain financial goals consisting of market share, customer acquisition, customer retention), level of customer satisfaction, level of customer profitability,

3) Internal and Business Perspective processes, provide an overview of processes that must be built to serve customers and to achieve certain financial goals, consists of three stages: innovation, operation, and after-sales service.

4) Learning and Growth perspective serves as a spur to build the competence of personnel, information systems facilities for pre and atmosphere of the work environment needed to achieve financial goals, customer, and internal business process consisting of employee Productivity, employee Turn Over and absent.

Analytic Hierarchy Process. Analytic Hierarchy Process (AHP) is a measurement theory through pairwise comparisons and depends on the assessment of experts to obtain priority scales. SAATY (1994) developed the AHP approach for the development of hierarchy and validation at Wharton Hospital of Business. This is an effective tool for handling complex decision making and can help decision makers to set priorities and make the best decisions. By reducing complex decisions into a series of paired comparisons, and then synthesizing the results, AHP helps capture the subjective and objective aspects of a decision. In addition, AHP combines techniques that are useful to check the consistency of decision-making evaluations, thereby reducing bias in the decision-making process (Thomas L. Saaty, 2016).

To decide in an organized way to generate priorities we need to decompose the decision into the following steps.

1) Define the problem and determine the kind of knowledge sought

2) Structure the decision hierarchy from the top with the goal of the decision, then the objectives from a broad perspective, through the intermediate levels (criteria on which subsequent elements depend) to the lowest level (which usually is a set of the alternatives).

3) Construct a set of pair wise comparison matrices. Each element in an upper level is used to compare the elements in the level immediately below with respect to it.

4) Use the priorities obtained from the comparisons to weigh the priorities in the level immediately below. Do this for every element. Then for each element in the level below add its weighed values and obtain its overall or global priority. Continue this process of weighing and adding until the final priorities of the alternatives in the bottom-most level are obtained.

AHP can be implemented in the following five stages.

1) Defining the Final Goal: The first step is to define the final goal that must be achieved in decision making.

2) Structuring Elements: In the second stage, what is done is to structure elements on criteria, sub-criteria, and alternatives. To make comparisons, we need a number scale that shows how many more important or dominant elements are above other elements in relation to the criteria or property associated with them shown in Table 1. below: 
Table 1 The fundamental scale of absolute numbers

\begin{tabular}{|l|l|}
\hline $\begin{array}{l}\text { Intensity of } \\
\text { Importance }\end{array}$ & \multicolumn{1}{|c|}{ Explanation } \\
\hline & \\
\hline 1 & Both elements are equally important \\
\hline 3 & One element is slightly more important than the other \\
\hline 7 & One element is more important than the other \\
\hline 9 & $\begin{array}{l}\text { One element is clearly more important than other } \\
\text { elements }\end{array}$ \\
\hline $2,4,6,8$ & One element is absolutely important than other elements \\
\hline $\begin{array}{l}\text { if } \mathrm{A} / \mathrm{B}=9 \\
\text { then } \mathrm{B} / \mathrm{A}=1 / 9\end{array}$ & $\begin{array}{l}\text { The values between the two values of consideration are } \\
\text { close together }\end{array}$ \\
\hline
\end{tabular}

Source: SAATY (1990)

3) Creating a Pairwise Comparison Matrix: The next step is to create a pairwise comparison matrix for each element in each group, by determining the coefficient of importance (weight) that refers to the goal. A set of paired comparison matrices $(m \times n)$ is created, where $m$ is the number of evaluation criteria considered.

4) Calculating Weight and Consistency Index: The results of pairwise comparisons are then used to weight the eigenvectors and the total number is taken from the overall eigenvector value corresponding to the lowest level of the hierarchy. Consistency is obtained by using the eigenvalues $\lambda$ max. To calculate the consistency index value $(\mathrm{CI})$ is used:

$\mathrm{CI}=(\lambda \max -\mathrm{n}) /(\mathrm{n}-1)$

With $\mathrm{CI}=$ consistency index, $\lambda \max =$ value, and $\mathrm{n}=$ matrix size. Then, the consistency ratio $(\mathrm{CR})$ is calculated using:

$\mathrm{CR}=\mathrm{CI} / \mathrm{RI}$

The consistency value can be checked by taking the CR value from $\mathrm{CI}$ with the value corresponding to Table II. The CR value is acceptable if it does not exceed 0.10 . If the CR value is $>0.10$, it means that the assessment matrix is inconsistent. To get a consistent matrix, the assessment must be re-examined and improved.

Table 2 Random Average

\begin{tabular}{|l|l|l|l|l|l|l|l|l|l|}
\hline $\begin{array}{c}\text { Matrix } \\
\text { Size }\end{array}$ & 2 & 3 & 4 & 5 & 6 & 7 & 8 & 9 & 10 \\
\hline IR & 0,00 &, 58 & 0.90 & 1,12 & 1,24 & 1,32 & 1,41 & 1,45 & 1,51 \\
\hline
\end{tabular}

Source: SAATY (1990)

\section{Research Methodology}

This research methodology was a process related step to solving the above problems. The stages of the research are described as follows:

1) Initial observation, problem formulation, and study objectives;

2) Literature review;

3) Performance Measurement in hospital: Balanced Scorecard and Analytic Hierarchy Process; 
4) Data Collection and Processing: Hospital performance measurement data, results of questionnaires at the Dr.TC. Hillers Hospital. Data processing for each perspective was using the AHP method. The data collection process begun with the identification of strategic objectives and key performance indicators in each perspective, namely customer perspective, finance, internal business processes, and growth and learning. It also carried out a pairwise comparison questionnaire from the Director and Head of the hospital, doctors, nurses and nonmedical personnel totaling 15 people. Having known the strategic objectives and key performance indicators then arranged in a hierarchy that showed the relationship of these criteria with the sub-criteria. After that, collecting data in hospital was in accordance with the strategic objectives and key performance indicators that have been arranged.

5) Analysis of research results contained analysis based on the results of data processing.

6) Conclusions contained conclusions based on the Dr.TC. Hillers Hospital related to the study objectives.

\section{Results and Discussion}

The benchmark used in this study uses references from Kaplan and Norton (2000).

1. Customer Perspective

Table 3 Measurement of Customer Acquisition

\begin{tabular}{|c|c|c|c|}
\hline Year & $\begin{array}{c}\text { Number of } \\
\text { Patients }\end{array}$ & New Patient & Acquisition \\
\hline 2015 & 76.256 & - & - \\
\hline 2016 & 82.369 & 6.113 & $8,01 \%$ \\
\hline 2017 & 90.249 & 7.880 & $9,56 \%$ \\
\hline
\end{tabular}

Source: Medical Record Section Dr. TC. Hillers Hospital

From table 3 above shows that Dr.TC. Hillers Hospital in 2015 - 2017 experienced an increase in acquisition every year. This means that hospital can attract new consumers, as evidenced by the number of new patients experiencing an increase.

Table 4 Measurement of Customer Retention

\begin{tabular}{|c|c|c|}
\hline Year & Number of Patients & Retention \\
\hline 2015 & 76.256 & - \\
\hline 2016 & 82.369 & $108,01 \%$ \\
\hline 2017 & 90.249 & $109,56 \%$ \\
\hline
\end{tabular}

Source: Medical Record Section Dr. TC. Hillers Hospital

From table 4 above shows that Dr.TC. Hillers Hospital in 2015 - 2017 experienced an increase in retention every year. This means that the hospital can retain old customers due to an increase in good medical personnel services and patients are satisfied with hospital services.

Table 5 Measurement of customer satisfaction

\begin{tabular}{|l|c|c|c|}
\hline \multicolumn{1}{|c|}{ Description } & 2015 & 2016 & 2017 \\
\hline Number of complaints & 326 & 241 & 228 \\
\hline Decrease in Number of Complaints & - & $26,07 \%$ & $5,39 \%$ \\
\hline Number of complaints handled & 216 & 235 & 183 \\
\hline Complaint Handling Ratio & $66,25 \%$ & $97,51 \%$ & $80,26 \%$ \\
\hline
\end{tabular}

Source: Medical Record Section Dr.TC. Hillers Hospital 
From Table 5 above shows that from 2015 - 2017 Dr. TC. Hillers Hospital experienced a decrease in the number of complaints. This means that the hospital has tried to meet the needs and satisfaction of patients. Complaint handling ratio has a significant increase. This means that the house is very maintaining patient satisfaction.

2. Financial Perspective

Table 6 Measurement of Revenue Growth

\begin{tabular}{|l|c|l|l|}
\hline \multicolumn{1}{|c|}{ Description } & \multicolumn{1}{c|}{2015} & \multicolumn{1}{c|}{2016} & \multicolumn{1}{c|}{2017} \\
\hline Realized revenue & 23.239 .864 .789 & 27.575 .245 .000 & 34.584 .268 .265 \\
\hline $\begin{array}{l}\text { Revenue Growth } \\
\text { Ratio }\end{array}$ & - & $18,65 \%$ & 25,41 \\
\hline
\end{tabular}

Source: Medical Record Section Dr. TC. Hillers Hospital

Table 6 above shows that 2015-2017 in Dr.TC. Hillers Hospital experienced an increase. This proves that hospital performance in generating income is good.

Table 7 Measurement of Changes in Costs

\begin{tabular}{|l|c|c|c|}
\hline \multicolumn{1}{|c|}{ Description } & 2015 & 2016 & 2017 \\
\hline Realization of Costs & 38.623 .475 .897 & 40.683 .250 .285 & 45.648 .359 .000 \\
\hline Cost change ratio & - & $5,33 \%$ & \\
\hline
\end{tabular}

Source: Medical Record Section Dr. TC. Hillers Hospital

Table 7 above shows that there is an increase in the use of costs so that hospitals in cost management are considered lacking. This is due to the availability of hospital facilities and infrastructure, the development of the competence of medical personnel so that the hospital in providing services to patients is more optimal where this has an impact on patient satisfaction.

3. Internal Business Process Perspective

Table 8 Measurement of the quality of the treatment process (effectiveness)

\begin{tabular}{|l|c|c|c|}
\hline \multicolumn{1}{|c|}{ Description } & 2015 & 2016 & 2017 \\
\hline Timeliness of service time, waiting time and processing time & $\begin{array}{c}20 \\
\text { minutes }\end{array}$ & $\begin{array}{c}15 \\
\text { minutes }\end{array}$ & $\begin{array}{c}10 \\
\text { minutes }\end{array}$ \\
\hline Service accuracy, which includes error free & $65 \%$ & $80 \%$ & $90 \%$ \\
\hline Courtesy and friendliness in providing services & $80 \%$ & $87 \%$ & $92 \%$ \\
\hline Ease of getting service & $80 \%$ & $85 \%$ & $85 \%$ \\
\hline $\begin{array}{l}\text { Convenience in obtaining services, related to location, } \\
\text { service space, parking space, availability of information and } \\
\text { others. }\end{array}$ & $80 \%$ & $90 \%$ & $95 \%$ \\
\hline $\begin{array}{l}\text { Other service supporting attributes such as air-conditioned } \\
\text { waiting rooms, cleanliness, and others. }\end{array}$ & $50 \%$ & $52 \%$ & $65 \%$ \\
\hline
\end{tabular}

Source: Processed data

From table 8 shows that the level of achievement of service quality is quite good. This is evidenced by the increasing percentage of service effectiveness during $2015-2017$. 
Table 9 Measurement of improved output quality

\begin{tabular}{|c|c|c|c|}
\hline Year & Number of Patients & Go home because healed & Percentage \\
\hline 2015 & 76.256 & 76.123 & $99,82 \%$ \\
\hline 2016 & 82.369 & 82.251 & $99,85 \%$ \\
\hline 2017 & 90.249 & 90.142 & $99,88 \%$ \\
\hline
\end{tabular}

Source: Medical Record Section Dr. TC. Hillers Hospital

Table 9 above shows that the quality of patient output at Dr. TC. Hillers Hospital in 2015-2017 is very good.

4. Learning and Growth Perspective

Table 10 Measurement of HR Quality Improvement for medical and non-medical personnel (capability)

\begin{tabular}{|l|c|c|c|}
\hline \multicolumn{1}{|c|}{ Information } & 2015 & 2016 & 2017 \\
\hline Number of training & 54 & 36 & 74 \\
\hline Number of employees & 254 & 273 & 312 \\
\hline Percentage & $21,25 \%$ & $13 \%$ & $23 \%$ \\
\hline
\end{tabular}

Source: Medical Record Section Dr. TC. Hillers Hospital

Table 10 above shows that hospital lacks opportunities for employees to take part in training in developing their competencies. This is proven by the achievement of a very low percentage and a very insignificant increase.

Table 11 Measurement of Information System

\begin{tabular}{|l|c|c|c|}
\hline Information & 2015 & 2016 & 2017 \\
\hline Performance & $35 \%$ & $50 \%$ & $52 \%$ \\
\hline Information & $25 \%$ & $35 \%$ & $55 \%$ \\
\hline Economic & $35 \%$ & $46 \%$ & $55 \%$ \\
\hline Control & $32 \%$ & $42 \%$ & $52 \%$ \\
\hline Efficiency & $35 \%$ & $45 \%$ & $55 \%$ \\
\hline Service & $35 \%$ & $47 \%$ & $53 \%$ \\
\hline
\end{tabular}

Source: Processed data

From table 11 above shows that Dr. TC. Hillers Hospital information system has not been implemented properly. This means that an integrated hospital information system has not been implemented.

Performance assessment. Weighting using interval sizes. The number of items measured is 9 items, so the assessment score in the Balanced Scorecard is as follows:

Table 12 Balanced Scorecard Assessment Score

\begin{tabular}{|l|c|c|l|}
\hline & Score & Total Score & \multicolumn{1}{c|}{ Description } \\
\hline Less & -1 & -9 & Achievement level below the standard/target \\
\hline Enough & 0 & 0 & Achievement level according to standard/target \\
\hline Well & 1 & 9 & Achievement level above standard/target \\
\hline
\end{tabular}

Source: MULYADI 2001 
The performance area limit is "less", "enough" and "well" as follows:

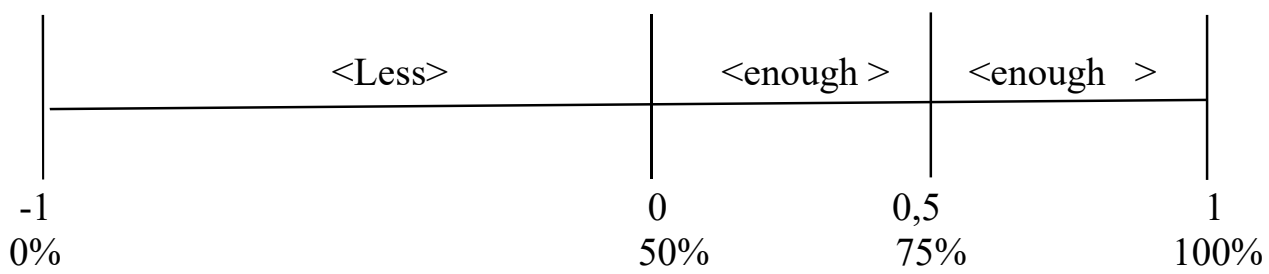

With such an assessment score in Table12 above, the performance Dr. TC. Hillers Hospital Balanced Scorecard as follows:

Table 13 Performance of Dr.TC. Hillers Hospital with Balance Scorecard:

\begin{tabular}{|l|c|c|}
\hline \multicolumn{1}{|c|}{ Information } & Criteria & Score \\
\hline Customer Perspective & & \\
\hline 1) Customer acquisition & Well & 1 \\
\hline 2) Customer retention & Well & 1 \\
\hline 3) Customer satisfaction & Well & 1 \\
\hline Financial Perspective & & \\
\hline 1) Revenue Growth & Well & 1 \\
\hline 2) Changes in Costs & Less & -1 \\
\hline Internal Business Process Perspective & Well & 1 \\
\hline 1) Quality of the treatment process (effectiveness) & Well & 1 \\
\hline 2) Quality of output & & \\
\hline 5. Learning And Growth Perspective & Less & -1 \\
\hline $\begin{array}{l}\text { 1) Quality Improvement of Human Resources for medical } \\
\text { and non-medical personnel }\end{array}$ & Less & -1 \\
\hline 2) Information System & & 6 \\
\hline Total Score & & \\
\hline
\end{tabular}

Source: Processed data

Researchers used performance measures with a total weight of scores of 9 for "good" and -9 for "less". Performance measurement results show that the score obtained is 6 . The average score is $6 / 9=0.67$ $(66.67 \%)$ so that it shows the performance of Dr. TC. Hillers Hospital: Good enough.

Identify KPI from Balance Scorecard. Key Performance Indicator (KPI) at the Dr.TC. Hillers can be seen in the following table: 
Table 14 Target Strategies and KPI from Balance Scorecard

\begin{tabular}{|c|c|c|c|c|}
\hline Target Strategy & Perspective & Perspective Code & KPI & Code KPI \\
\hline Customer acquisition & \multirow{3}{*}{ Customer } & \multirow[t]{3}{*}{$\mathrm{P} 1$} & Market Share & $\mathrm{C} 1$ \\
\hline Customer retention & & & Customer retention & $\mathrm{C} 2$ \\
\hline Patient satisfaction & & & Patient satisfaction & $\mathrm{C} 3$ \\
\hline Increased hospital income & \multirow[t]{2}{*}{ Financial } & \multirow[t]{2}{*}{$\mathrm{P} 2$} & $\begin{array}{l}\text { Increased hospital } \\
\text { income }\end{array}$ & F1 \\
\hline Cost Efficiency & & & Cost Growth & F2 \\
\hline $\begin{array}{l}\text { Quality improvement of the } \\
\text { maintenance process } \\
\text { (efficiency) }\end{array}$ & \multirow[t]{2}{*}{$\begin{array}{l}\text { Internal } \\
\text { Business } \\
\text { Process }\end{array}$} & \multirow[t]{2}{*}{ P3 } & $\begin{array}{l}\text { Operational Process } \\
\text { (Effectiveness) }\end{array}$ & BI1 \\
\hline $\begin{array}{l}\text { Improved output quality (The } \\
\text { number of patients recovering } \\
\text { increases) }\end{array}$ & & & Number of visits & BI2 \\
\hline $\begin{array}{l}\text { Quality improvement of human } \\
\text { resources for medical and non- } \\
\text { medical personnel }\end{array}$ & \multirow[t]{2}{*}{$\begin{array}{l}\text { Learning and } \\
\text { Growth }\end{array}$} & \multirow[t]{2}{*}{ P4 } & $\begin{array}{l}\text { Increased employee } \\
\text { commitment (medical } \\
\text { and non-medical) }\end{array}$ & LG1 \\
\hline $\begin{array}{l}\text { Integrated Hospital Information } \\
\text { System }\end{array}$ & & & $\begin{array}{l}\text { Information System } \\
\text { Hospital }\end{array}$ & LG2 \\
\hline
\end{tabular}

After a strategy and key performance indicator are made, a Strategy Map can be formulated to see the linkages between established strategic objectives which are a description of the linkages between strategic objectives in each perspective. Strategy Map of Dr.TC. Hillers Hospital can be shown in Figure 1. Following:

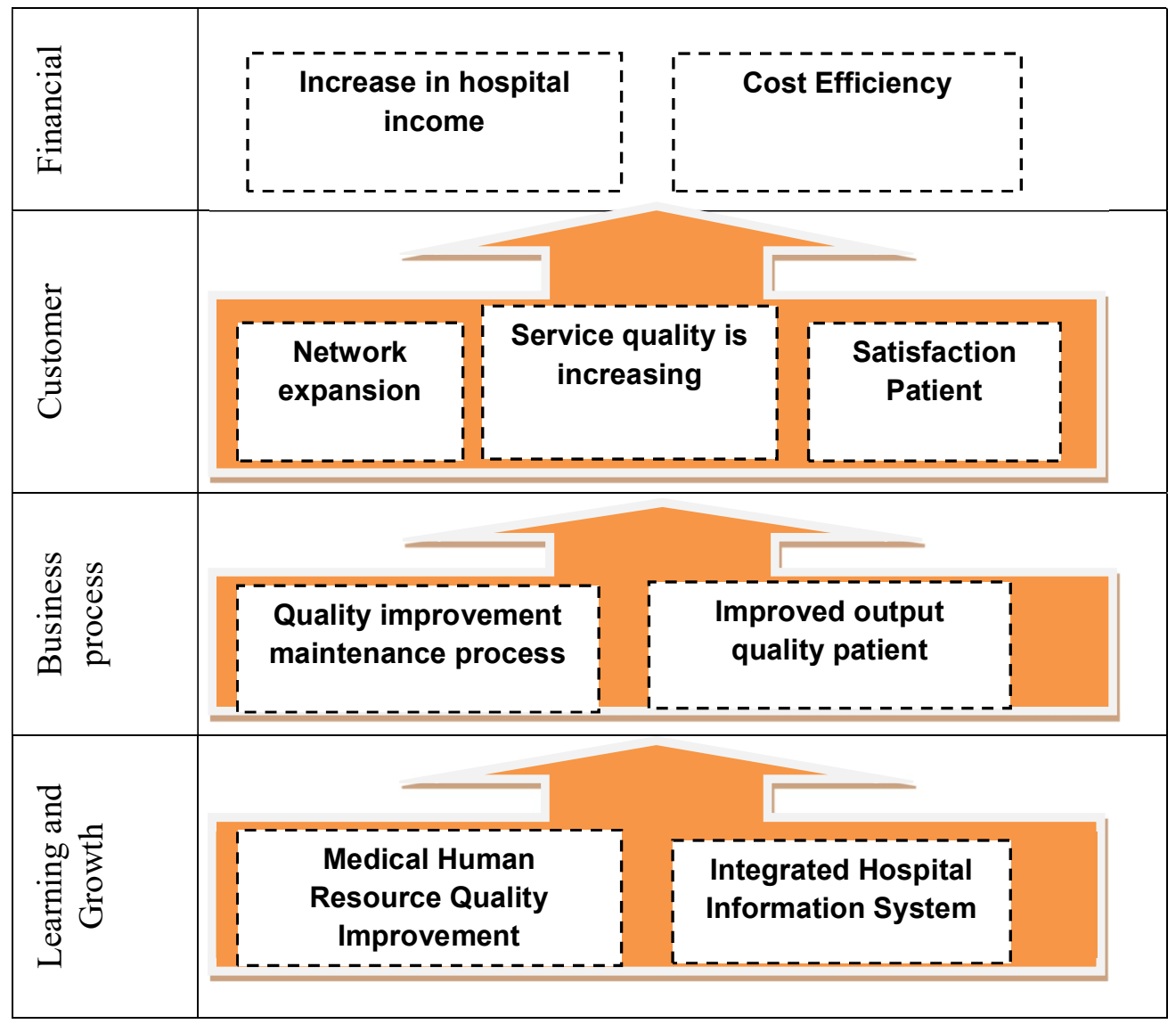

Figure 1 Strategy Map 
Data processing using Analytic Hierarchy Process (AHP) Method. Look for Priority weights

Table 15 Pair Comparison Matrix

\begin{tabular}{|l|c|c|c|c|c|}
\hline Perspective & Customer & Finance & $\begin{array}{c}\text { Internal } \\
\text { Business } \\
\text { Process }\end{array}$ & $\begin{array}{c}\text { Learning and } \\
\text { growth }\end{array}$ & $\begin{array}{c}\text { Priority } \\
\text { Vector }\end{array}$ \\
\hline Customer & 1 & 1,5 & 2 & 2,5 & 1,5307 \\
\hline Finance & 0,67 & 1 & 0,5 & 0,33 & 0,5621 \\
\hline $\begin{array}{l}\text { Internal } \\
\text { Business } \\
\text { Process }\end{array}$ & 0.50 & 2 & 1 & 0,5 & 0,7589 \\
\hline $\begin{array}{l}\text { Learning } \\
\text { and growth }\end{array}$ & 0,40 & 3,03 & 2 & 1 & 1,1546 \\
\hline & 2,56 & 7,53 & 5,5 & 4,3 & 4 \\
\hline
\end{tabular}

\section{Source: Processed data}

Based on the table calculation above, the priority is on the perspective of internal business processes $(75.89 \%)$, then finance perspective $(56.21 \%)$, customer perspectives $(53.07 \%)$ and learning and growth perspective $(15.46 \%)$.

Determine the value of the elements of each column.

Customer: $1+1.5+2+2.5=7$

Finance: $0.67+1+0.5+0.33=2.54$

Internal Business: $0.50+2+1+0.5=4$

Learning and Growth: $0.40+3.03+2+1=6.43$

Table 16 Results of Criteria Normalization Matrix

\begin{tabular}{|l|l|l|l|l|l|}
\hline Criteria & Customer & Finance & $\begin{array}{l}\text { Internal } \\
\text { Business } \\
\text { Process }\end{array}$ & $\begin{array}{l}\text { Learning and } \\
\text { Growth }\end{array}$ & Number \\
\hline Customer & 0,1428 & 0,2142 & 0,2857 & 0,3571 & 0,9998 \\
\hline Finance & 0,2637 & 0,3937 & 0,1968 & 0,1299 & 0,9841 \\
\hline $\begin{array}{l}\text { Internal Business } \\
\text { Process }\end{array}$ & 0,125 & 0,5 & 0,25 & 0,125 & 1 \\
\hline $\begin{array}{l}\text { Learning and } \\
\text { Growth }\end{array}$ & 0,0622 & 0,4712 & 0,3110 & 0,1555 & 0,9999 \\
\hline
\end{tabular}

Source: Processed data

Determining Weighting Criteria.

Customer: $0.9998 / 4=0.2499$

Finance: $0.9841 / 4=0.2460$

Internal Business Process: $1 / 4=0.25$

Learning and Growth: $0.9999 / 4=0.2499$

From the results of the calculation of global weight recapitulation for each perspective obtained results that the perspective of the Internal Business Process (P3) obtain the highest global weight of $25 \%$, then the learning and growth perspective (P4) of $24.99 \%$, the customer perspective (P1) $24.99 \%$ and financial perspective (P2) which has a global weight of $24.60 \%$.

Determine the weighting of each KPI. 
Table 17 Calculation of the weight of each KPI and the target of the Strategy

\begin{tabular}{|l|l|c|c|}
\hline \multicolumn{1}{|c|}{ Target Strategy } & \multicolumn{1}{|c|}{ KPI } & Code KPI & Weight \\
\hline Network expansion & Market Share & C1 & 0,0303 \\
\hline Service Quality Improvement & Patient Retention & C2 & 0,1262 \\
\hline Increased patient satisfaction & Patient satisfaction & C3 & 0,0933 \\
\hline Increased revenue growth & Revenue Growth & F1 & 0,1376 \\
\hline Cost Efficiency & Cost Efficiency & F2 & 0,1084 \\
\hline $\begin{array}{l}\text { Improving the quality of the care } \\
\text { process }\end{array}$ & $\begin{array}{l}\text { Operational Process } \\
\text { (Effectiveness) }\end{array}$ & BI2 & 0,1614 \\
\hline $\begin{array}{l}\text { Improving the quality of patient } \\
\text { output }\end{array}$ & Patients who go out recover & BI3 & 0,0886 \\
\hline $\begin{array}{l}\text { Improving the quality of human } \\
\text { resources }\end{array}$ & $\begin{array}{l}\text { Increased employee } \\
\text { commitment }\end{array}$ & LG1 & 0,1223 \\
\hline $\begin{array}{l}\text { Integrated RS Information } \\
\text { System }\end{array}$ & $\begin{array}{l}\text { Hospital Information } \\
\text { System }\end{array}$ & LG2 & 0,1276 \\
\hline Total Weight & & 1,00 \\
\hline
\end{tabular}

Source: Processed data

Determine the Value of the Consistency Index $(\mathrm{CI})$. Principal Eigen Value $=(2.56 \times 1.5307)+(7.53$ $\times 0.5621)+(5.5 \times 0.7589)+(4.3 \times 1.1546) / 4=4 \bullet$ Calculate Consistency Index $(\mathrm{CI})$ with the formula: $C I=(\max -n) /(n-1)$, for $n=4 C I=(4.00-4) /(4-1)=0, C I$ equals 0 means that the weighting is very consistent.

Looking for Consistency Ratio (CR) Value. Calculating Consistency Ratio (CR) is obtained by the formula $\mathrm{CR}=\mathrm{CI} / \mathrm{RI}$, the value of RI depends on the number of criteria as in the following table:

\begin{tabular}{|c|c|c|c|c|c|c|c|c|c|c|}
\hline $\mathrm{n}$ & 1 & 2 & 3 & 4 & 5 & 6 & 7 & 8 & 9 & 10 \\
\hline $\mathrm{RI}$ & 0 & 0 & 0,58 & 0,9 & 1,12 & 1,24 & 1,32 & 1,41 & 1,45 & 1,49 \\
\hline
\end{tabular}

So for $\mathrm{n}=4, \mathrm{RI}=0.9, \mathrm{CR}=\mathrm{CI} / \mathrm{RI}=0.0 / 0.9=0.0$ The results of $\mathrm{CR}$ calculation are less than $10 \%$, so the weighting is very consistent.

Determine Strategy Priorities. Calculation in previous steps can then be determined priority strategies that can be implemented in Dr. TC. Hillers can be seen in the following table: 
Table 18 Program Priorities

\begin{tabular}{|l|l|c|c|c|c|}
\hline No & Proposed program & Code KPI & $\begin{array}{l}\text { Weight } \\
\text { KPI }\end{array}$ & $\begin{array}{l}\text { Percentage e } \\
\text { KPI (\%) }\end{array}$ & $\begin{array}{l}\text { Priority } \\
\text { strategy }\end{array}$ \\
\hline 1 & Network expansion & C1 & 0,0303 & 3,03 & 1 I \\
\hline 2 & $\begin{array}{l}\text { Service Quality } \\
\text { Improvement }\end{array}$ & C2 & 0,1262 & 12,62 & III \\
\hline 3 & $\begin{array}{l}\text { Increased patient } \\
\text { satisfaction }\end{array}$ & C3 & 0,0933 & 9,33 & VII \\
\hline 4 & $\begin{array}{l}\text { Increased revenue } \\
\text { growth }\end{array}$ & F1 & 0,1376 & 13,76 & II \\
\hline 5 & Cost Efficiency & F2 & 0,1084 & 10,84 & VI \\
\hline 6 & $\begin{array}{l}\text { Improving the } \\
\text { quality of the care } \\
\text { process }\end{array}$ & BI2 & 0,1614 & 16,14 & I \\
\hline 7 & $\begin{array}{l}\text { Improving the } \\
\text { quality of patient } \\
\text { output }\end{array}$ & BI3 & 0,0886 & 8,86 & VIII \\
\hline 8 & $\begin{array}{l}\text { Improving the } \\
\text { quality of human } \\
\text { resources }\end{array}$ & LG1 & 0,1223 & 12,23 & V \\
\hline 9 & $\begin{array}{l}\text { Integrated RS } \\
\text { Information System }\end{array}$ & LG2 & 0,1276 & 12,76 & IV \\
\hline
\end{tabular}

Source: Processed data

Table 18 shows that with the use of the AHP method, all alternative problem solving (health programs at Dr. TC. Hillers Hospital) can be determined properly.

From the analysis, it was found that the strategy for improving the quality of the treatment process was the first priority $(16.14 \%)$, then an increase in income growth (13.76\%), improving service quality $(12.62 \%)$, improving the quality of HR (15.23\%), increasing revenue growth (13.76\%), integrated Hospital Information System (12.76), Improving the quality of HR (12.23), Cost Efficiency $(10.84 \%)$, increasing patient satisfaction $(9.33 \%)$ and improving the quality of patient output $(8.86 \%)$ and network expansion (3.03\%).

\section{Conclusion}

Based on the discussion in the previous section, it can be concluded that:

1. The results of hospital performance measurement Dr. TC. Hillers Hospital 2015-2017 period showed that the score obtained is 6 . The average score is $6 / 9=0.67(66.67 \%)$ that shows the performance of hospitals Dr.TC. Hillers: Good enough.

2. With the AHP method the program strategy that gets priority is a strategy for improving the quality of the care process in the priority $(16.14 \%)$, then increasing income growth $(13.76 \%)$. improving service quality $(12.62 \%)$, improving the quality of HR $(15.23 \%)$, increasing revenue growth (13.76\%), integrated Hospital Information System (12.76), improving the quality of HR (12.23), Cost efficiency (10.84\%), increasing patient satisfaction (9.33\%) and improving in the quality of patient output $(8.86 \%)$ and network expansion $(3.03 \%)$.

\section{References}

Bourne, M., Neely, A., Platts, K., \& Mills, J. (2002). The success and failure of performance measurement initiatives. International Journal of Operations \& Production Management, 22(11), 1288-1310. 
Changgu Lee,1,2 Xiaoding Wei,1 Jeffrey W. Kysar,1, 3 James Hone. (2008). Measurement of the Elastic Properties and Intrinsic Strength of Monolayer Graphene. SCIENCE, 321.

Chavan, M. (2009). The balanced scorecard: a new challenge. Journal of Management Development, 28(5), 393-406.

David OtleyU. (1999). Performance management: a framework for management control systems research. Management Accounting Research, 10, 363]382.

G. Ross Baker and George H. Pink. (1995). No TitleA Balanced Scorecard for Canadian Hospitals. Winter/Hiver, 8 .

Gerhard Speckbacher, Juergen Bischof, Thomas Pfeiffer. (2003). A descriptive analysis of the implementation of Balanced Scorecards in German-speaking countries. Management Accounting Research, 361-387.

Greiling, D. (2010). Balanced scorecard implementation in German non-profit organizations. International Journal of Productivity and Performance Management, 59(6), 534-554.

Hanne NørreklitU. (2000). The balance on the balanced scorecard - a critical analysis of some of its assumptions. Management Accounting Research, 11, 65-88.

Helen Atkinson. (2006). Strategy implementation: a role for the balanced scorecard? Management Decision, 44(1441-1460).

Hussein Aljardali, Mazen Kaderi, T. L.-T. c. (2012). The implementation of the balanced scorecard in Lebanese public higher education institutions. Procedia - Social and Behavioral Sciences, 62, $98-108$.

Marr, B., \& Schiuma, G. (2003). Business performance measurement - past, present, and future. Management Decision, 41(8), 680-687.

Michael Beer and Russell A.Eisenstat. (1996). Developing an Organization Capable of Implementing Strategy and Learning. Human Relation, 49.

MichaelGooldAndrewCampbell. (1991). Briefcase: From corporate strategy to parenting advantage. Long Range Planning, 24.

Mulyadi,2001. Balanced Scoreard-Alar Manajemen Kontemporer Untuk Pelipatgandadaan Kinerja keuangan Perusahaan. Jakarta:Salemba Empat.

Peter C.Brewer. (2000). Using The Balanced Supply Chain Performance. Journal of Business Logistics, 21.

Robert S.Kaplan and David Norton. (1996). Using The Balanced Scorecard as a Strategic Management System. Harvard Business Review.

Schäffer, U., \& Matlachowsky, P. (2008). Warum die Balanced Scorecard nur selten als strategisches Managementsystem genutzt wird. Zeitschrift Für Planung \& Unternehmenssteuerung, 19(2), 207-232.

Scott M. Shafer, *, H. Jeff Smitha, J. C. L. (2015). The power of business models. Business Horizons, 45, 199-207.

Teemu Malmi. (2001). Balanced scorecards in Finnish companies: A research note. Management Accounting Research, 12, 207-220.

Thomas L. Saaty. (1980). Marketing Application of Analytic Hierarchy Process. Management Science, 26.

Thomas L. Saaty. (2008). Decision making with the analytic hierarchy process. Int. J. Services Sciences, 1 .

Thomas L. Saaty. (2016). Axioms of the Analytic Hierarchy Process (AHP) and its Generalization to Dependence and Feedback: The Analytic Network Process (ANP). 